\title{
Arvot
}

\section{nuorten aikuisten vapaaehtoistoiminnassa}

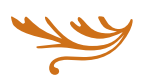

Yli kolmannes suomalaisista osallistuu vapaaehtoistoimintaan, mutta ilmiötä on tutkittu vähän suhteessa arvoihin. Klassisten kehitysteorioiden mukaan nuori aikuisuus on aikaa, jolloin identiteetti ja oikean ja väärän kysymykset kypsyvät. Artikkelissa tarkastellaan nuorten aikuisten vapaaehtoistoiminnan taustalla vaikuttavia arvoja.

VAPAAEHTOISTOIMINNALla tarkoitetaan palkatonta, vapaasta tahdosta tapahtuvaa, länsimaisessa kontekstissa yleensä organisoitua yhteisten asioiden edistämistä tai toisten ihmisten auttamista pois lukien oma lähipiiri. Vapaaehtoistoiminnan merkitys on kansantaloudellisesti suuri, mutta vielä suurempi on toiminnan vaikutus yhteiskunnan toimivuuteen, ihmisten väliseen luottamukseen, solidaarisuuteen ja välittämisen eetokseen. Ilmiönä vapaaehtoistoiminta onkin mitä yhteiskunnallisin. (State of the World's Volunteerism Report 2011).

Samaan aikaan vapaaehtoisuus on myös mitä henkilökohtaisin asia, nimensä mukaisesti yksilön vapaaseen tahtoon perustuvaa toimintaa, johon ei vie pakko, taloudellinen palkkio tai Suomen tapauksessa usein myöskään kulttuurinen normi. Suomalaisen vapaaehtoistoiminnan taustalla on henkilökohtainen motivaatio, useimmin jonkinlainen auttamishalun ja muiden motiivien yhdistelmä (esim. Nylund \& Yeung 2005) sekä holistisen motivaatiokäsityksen mukaisesti yksilön arvot, identiteetti ja elämänkatsomus (Grönlund 2011; Pessi 2008). Yli kolmannes suomalaisista osallistuu vapaaehtoistoimintaan (Pessi 2008; Study on Volunteering in the European Union 2011; Yeung 2001). Nuorten ikäryhmien osallistuminen organisoituun vapaaehtoistoimintaan on lähes yhtä yleistä (Grönlund \& Pessi 2008).

Tämä artikkeli tarkastelee vapaaehtoistoiminnan ja arvojen yhteyksiä Suomessa, ja analysoi vapaaehtoistoiminnan roolia suomalaisessa yhteiskunnassa yksilöiden merkityksenantojen kautta. Tutkimusaineisto koostuu 24 elämäkaaritemaattisesta haastattelusta vapaaehtoisena toimiville nuorille aikuisille. ${ }^{1}$

Aiempi yksilöiden vapaaehtoistoimintaa käsittelevä tutkimus on tarkastellut ilmiötä erityisesti sosio-ekonomisten muuttujien ja motiivien näkökulmasta. Tutkimuksessa on etsitty iän, sukupuolen, ammatin, koulutuksen tai asuinmaan yhteyksiä toimintaan tai sen motiiveihin 
(Musick \& Wilson 2008; Rochester et al. 2010; Suomessa esim. Pessi 2008; Yeung 2001). Samoja kysymyksiä käsitellään myös nuorten aikuisten vapaaehtoistoimintaan keskittyvässä tutkimuksessa (esim. Marta \& Pozzi 2008; Rehberg 2005; Suomessa Grönlund \& Pessi 2008). Lähes kaikki vapaaehtoistoiminnan motivaatiota käsittelevät tutkimukset ovat tunnistaneet altruismiin eli epäitsekkyyteen, oppimiseen, urapyrkimyksiin ja sosiaalisuuteen liittyviä motiiveja. Alan tutkimus käyttää vakiintuneesti jaotteluja itseen ja muihin orientoituviin motiiveihin sekä sisäisiin ja ulkoisiin motiiveihin. (Clary et al. 1998; Musick \& Wilson 2008; Suomessa esim. Nylund \& Yeung 2005). Nuorten aikuisten motiivit näyttäytyvät erityisen moniulotteisina ja vaihtelevina. Heille näyttää olevan tyypillistä yhdistellä erilaisia motiiveja refleksiivisellä ja yksilöllisellä tavalla (Marta \& Pozzi 2008).

Altruistiset, humanitaariset, ja uskonnolliset arvot on yhdistetty vapaaehtoisena toimimiseen, ja niitä pidetään yleisesti osana vapaaehtoistoimintaan ohjaavaa motivaatiota (esim. Musick \& Wilson 2008). Sitä, miten yksilöt kokevat nämä arvot vapaaehtoistoiminnassa tai miten ne linkittyvät heidän identiteettiinsä, on kuitenkin tutkittu vähän. Ylipäätään tutkimuksia, jotka pyrkisivät ymmärtämään vapaaehtoistoiminnan roolia yksilöiden elämässä laajemmin, on tehty vähän. Tämä artikkeli vastaa aiheellaan osaltaan tähän vajeeseen.

\section{TEOREETTINEN TAUSTA: NARRATIIVINEN IDENTITEETTI JA ARVOT}

Identiteetti voidaan määritellä yksilön käsitykseksi itsestään, hänelle tärkeistä kyvyistä, rooleista, arvoista, taustasta ja viiteryhmistä. Identiteetin muodostus ja ylläpito ovat yksilön tärkeimpiä tarpeita (Blasi 1993; Erikson 1968). Tätä refleksiivistä prosessia on kuvattu elämäntarinan neuvotteluksi, jonka avulla yksilö voi tuoda logiikkaa ja koherenssia identiteettiinsä. McAdams käyttää narratiivisen identiteetin käsitettä ja määrittelee elämäntarinan sisäiseksi, kehittyväksi kognitiiviseksi rakenteeksi, joka tuo merkitystä ja tarkoitusta yksilön elämään (McAdams, 2006). Yksilö voi myös jakaa näitä sisäisiä konstruktioitaan toisten kanssa. Narratiiviset tutkimusmenetelmät tarjoavat yhden välineen tähän.
Arvot voidaan määritellä verrattain pysyviksi, tavoiteltaviksi päämääriksi, jotka ohjaavat yksilöiden tai ryhmien toimintaa (Rokeach 1973; Schwartz 1992). Schwartz (1992) on tunnistanut 10 inhimillistä perusarvoa, jotka tunnistetaan eri yhteiskunnissa ja jotka motivoivat toimintaa eri tavoin. Ne ovat: valta, suoriutuminen, hedonismi, virikkeisyys, itseohjautuvuus, universalismi, hyväntahtoisuus, perinteet, yhdenmukaisuus, ja turvallisuus. Perusarvot jakautuvat kahdelle polaariselle ulottuvuudelle: itsensä korostaminen-itsensä ylittäminen sekä säilyttävyys-muutokselle avoimuus.

Arvoja pidetään normatiivisina ja oikeutettuina, mutta ne ovat usein myös emotionaalisia ja osin tiedostamattomia (Schwartz 1992). Narratiiviset ja elämäntarinalliset lähestymistavat mahdollistavat sellaisten alueiden ja teemojen tavoittamisen, jotka eivät ole helposti sanoitettavia, kuten arvot. Hitlinin (2007) mukaan arvojen ja identiteetin mukaisesti toimiminen on tärkeä osa itsen hyväksymistä. Vapaaehtoistoiminnan kautta yksilö voi toteuttaa itsemäärittelyn prosessia, jos hän kokee, että hänen perusarvonsa toteutuvat siinä. Näin ollen vapaaehtoistoimintaa ja siihen liittyviä prosesseja voidaan ymmärtää syvemmin identiteetin ja arvojen kautta. McAdamsin (2001) mukaan narratiivisten identiteettien konstruointi alkaa myöhäisessä nuoruudessa ja varhaisaikuisuudessa. Myös klassisten kehitysteorioiden mukaan nuori aikuisuus on aikaa, jolloin identiteetti ja oikean ja väärän kysymykset kypsyvät (Erikson 1968; Kohlberg 1975). Nuoret aikuiset ovat siis mielenkiintoinen ryhmä narratiivisen identiteetin, arvojen ja vapaaehtoistoiminnan tutkimiseen.

Tässä artikkelissa narratiivisen identiteetin lähestymistapaa hyödynnetään näkökulmana niihin prosesseihin, joilla vapaaehtoiset antavat merkityksiä vapaaehtoistoiminnalle. Arvot ohjaavat narratiivisen identiteetin konstruointia ja siitä kertomista. Näin ollen narratiivisen identiteetin hahmot välittävät tietoa myös yksilön arvoista, joita tässä tutkimuksessa etsitään myös muista arvoarvostelmista ja merkityksenannoista. Sekä narratiivisen identiteetin konstruointien että arvoarvostelmien välityksellä löydettyjä arvoja analysoidaan ja Schwartzin (1992) arvoteorian avulla. 


\section{TUTKIMUSAINEISTO JA MENETELMÄ}

Tutkimuksen pääaineisto muodostuu 24 elämäkaaritemaattisesta haastattelusta, jotka on tehty Suomessa, pääkaupunkiseudulla asuville vapaaehtoisille, iältään 21-36 vuotta (12 naista, 12 miestä). ${ }^{2}$ Haastattelut toteutettiin talvella 2004-2005. Haastatellut toimivat vapaaehtoisina erilaisissa järjestöissä ja yhteisöissä esimerkiksi urheilussa, sosiaali- ja terveysalalla, kansainvälisessä avustustoiminnassa, kulttuurin alalla, uskonnollisessa toiminnassa sekä lasten ja nuorten parissa. Vapaaehtoistoiminta, sen eri vaiheet, toimintaorganisaatiot ja toiminnan motivaatio muodostivat haastattelujen punaisen langan. Lisäksi käsiteltiin haastateltavien elämänvaiheita lapsuudesta tulevaisuuden toiveisiin rohkaisten narratiivisiin vastauksiin ja pohdintaan. Muita teemoja olivat viiteryhmät kuten lapsuuden perhe, ystävät, puoliso ja mahdolliset lapset, yhteiskunnallinen konteksti eli suomalainen yhteiskunta, politiikka ja niihin vaikuttaminen sekä uskonnollisuus (haastatteluaineiston ja analyysin tarkempi kuvaus, ks. Grönlund 2012a).

Jokainen haastattelu luettiin ensin läpi useita kertoja pyrkimyksenä muodostaa siitä kokonaisvaltainen ymmärrys. Haastatteluista seitsemässätoista vapaaehtoistoiminta kietoutui yhteen haastateltavalle tärkeiden arvojen kanssa, seitsemässä ei. Seitsemän haastateltavaa määritteli vapaaehtoistoiminnan tavalla, jossa toiminnalla ei ollut heille suurta merkitystä. Nämä haastateltavat kokivat usein ajautuneensa vapaaehtoistoimintaan ilman selkeää päätöstä tai valintaa. Analyysissä keskityttiin ensin mainittuihin 17 haastatteluun. Niistä etsittiin itsen kuvauksia, joita voidaan pitää elämäntarinoiden hahmoina: tarinoiden eri vaiheiden negatiivisia tai positiivisia kuvia itsestä, jotka edustavat kertojan eri puolia ja reflektoivat usein myös sosiaalista ympäristöä, johon kertoja itsensä sijoittaa. Yhdessä haastattelussa voi esiintyä useita hahmoja. Positiivisten hahmojen tulkittiin analyysissä edustavan haastateltavan näkemystä narratiivisesta identiteetistään, jotakin, johon he samaistuivat, negatiivisten taas torjuttuja identiteettejä, jotakin, johon haastateltavat eivät halunneet samaistua lainkaan tai enää (ks. McAdams 2006).

Ihmisen kertomus elämästään on aina subjektiivinen ja sitä voidaan käyttää erityisesti sen ymmär- tämiseen, miten yksilö tulkitsee, ymmärtää ja reflektoi itseään ja elämäänsä, menneisyyttään ja tulevaisuuttaan haastattelun ajankohtana (Roberts 2002). Arvot ja uskomukset vaikuttavat aina narratiivisen identiteetin konstruoimiseen. Taylorin (1989) mukaan identiteetin luominen narraation kautta käsittelee yleensä moraalisia kantoja, viittaa implisiittisiin näkemyksiin hyvästä. Itsen, muiden, ilmiöiden ja tapahtumien arviointi elämäntarinassa tuo siten informaatiota yksilön arvoista ja uskomuksista. Haastateltavien arvoja analysoitiin tämänkaltaisten arviointien kautta.

Jokaisesta 17 haastattelusta luotiin holistinen käsitys haastattelussa esiintyvien hahmojen, arvojen ja vapaaehtoistoiminnalle annettujen merkitysten avulla. Haastateltavat ryhmiteltiin keskeisten arvojensa mukaan viiteen arvoidentiteettiryhmään sen mukaan, mitkä olivat tärkeimmät arvot, joihin he samaistuivat ja liittivät vapaaehtoistoimintansa suurimmat merkitykset. Nämä viisi tyyppiä ovat osin päällekkäisiä. Tapa, jolla vapaaehtoiset käyttivät vapaaehtoistoimintaa osana identiteettityötään, oli eri ryhmissä samankaltainen. Tutkimuksen yhtenä tuloksena voidaankin pitää narratiivisen identiteetin reflektoinnin kuvaamista sekä sen osoittamista, että vapaaehtoistoiminta on monilla haastatellulla osa näitä refleksiivisiä prosesseja. Siinä, missä narratiivisen identiteetin reflektointi kuvastaa prosessia, jolla merkityksiä luodaan ja käsitellään, arvoidentiteetin käsitettä käytetään kuvaamaan narratiivisten identiteettien arvosisältöjä eli konstruointeja ohjaavia arvoja. Tietyillä arvoidentiteettiryhmillä oli osin yhteisiä arvoja. Muodostetut viisi arvoidentiteettityyppiä eivät ole tarkkarajaiset vaan muodostavat pikemminkin jatkumon niistä erilaisista arvoulottuvuuksista tai painotuksista, joita vapaaehtoistoiminnassa toteutettiin.

\section{TULOKSET}

Seuraavaan taulukkoon 1 on tiivistetty kunkin arvoidentiteettiryhmän vapaaehtoisten vapaaehtoistoiminnalleen antamat motiivit, heille tärkeät arvot heidän omilla sanoillaan, sekä samat arvot Schwartzin (1992) arvoteorian käsittein.

Vaikuttaja-identiteettiryhmään ryhmiteltiin neljä haastateltavaa (M1, N4, M11, N11). Heitä yhdisti 
Taulukko 1. Arvoidentiteetit vapaaehtoistoiminnassa.

\begin{tabular}{|c|c|c|c|}
\hline $\begin{array}{l}\text { Arvo- } \\
\text { identiteetti }\end{array}$ & Motiivit omin sanoin & Arvot omin sanoin & $\begin{array}{l}\text { Arvot (ja niiden } \\
\text { suuntautuminen) arvoteorian } \\
\text { näkökulmasta (Schwartz 1992) }\end{array}$ \\
\hline Vaikuttajat & $\begin{array}{l}\text { Maailmasta parempi paikka, sen tekeminen, } \\
\text { mikä on oikein, vaikuttaminen, taistelu } \\
\text { epäoikeudenmukaisuutta vastaan }\end{array}$ & $\begin{array}{l}\text { Kriittisyys, solidaarisuus, } \\
\text { oikeudenmukaisuus }\end{array}$ & $\begin{array}{l}\text { Universalismi, itseohjautuvuus } \\
\text { (itsen ylittäminen, avoimuus } \\
\text { muutokselle) }\end{array}$ \\
\hline Auttajat & Toisten auttaminen & Auttaminen, välittäminen, empatia & $\begin{array}{l}\text { Hyväntahtoisuus } \\
\text { (itsen ylittäminen, säilyttävyys) }\end{array}$ \\
\hline Yhteisölliset & $\begin{array}{l}\text { Perheen kanssa oleminen, jonkin antaminen } \\
\text { yhteisölle, yhteisön osana oleminen }\end{array}$ & $\begin{array}{l}\text { Yhteisöllisyys, vastuullisuus, } \\
\text { perhearvot }\end{array}$ & $\begin{array}{l}\text { Perinteet, mukautuminen, } \\
\text { hyväntahtoisuus } \\
\text { (säilyttävyys) }\end{array}$ \\
\hline Uskonnolliset & $\begin{array}{l}\text { Evankeliumin levittäminen, Jumalan työn } \\
\text { tekeminen, lähimmäisen rakastaminen, } \\
\text { Kristittyjen parissa oleminen, kutsumus }\end{array}$ & Kristilliset arvot, auttaminen & $\begin{array}{l}\text { Hyväntahtoisuus, perinteet, } \\
\text { mukautuminen } \\
\text { (itsen ylittäminen, säilyttävyys) }\end{array}$ \\
\hline Suorittajat & $\begin{array}{l}\text { Suoriutumisen ja aikaan saamisen tunne, } \\
\text { velvollisuuden täyttäminen (toisten } \\
\text { auttamiseksi), kontaktien saaminen, } \\
\text { menestyminen }\end{array}$ & $\begin{array}{l}\text { Vastuullisuus, riippumattomuus, } \\
\text { pärjääminen/menestyminen }\end{array}$ & $\begin{array}{l}\text { Valta, suoriutuminen, } \\
\text { turvallisuus } \\
\text { (itsen korostaminen, } \\
\text { säilyttävyys) }\end{array}$ \\
\hline
\end{tabular}

kriittisyys ja analyyttisyys sekä halu vastustaa epäoikeudenmukaisuutta. Seuraava lainaus kuvastaa tätä orientaatiota hyvin:

"meil on nykyaikana tai nykyään niin paljon kaikkee. --- Ni mä ajattelen heti niin, et mikä on meille lisää, on joiltaki muilta pois, et --- mun mielest meil on jo ihan tarpeeks. Eli on nyt jo aika rupee antaan niille muille jotain. (M1, 25-vuotias mies, vapaaehtoisena kansainvälisessä auttamistyössä ja poliittisessa toiminnassa).

Tähän ryhmään kuuluvat toimivat vapaaehtoisina myös ihmisoikeuksien, luonnonsuojelun ja vammaiskysymysten parissa. Yksi tämän ryhmän haastateltava korostaa oman vaikuttamismotiivinsa merkitystä:

"et mä en ikinä tekis.. tai siis niinku vois kuvitellakaan tekeväni vapaaehtoistyötä vaan vapaaehtoistyön takia. Et kyl mul niinku aina liittyy se tähän vammaisuus-näkökulmaan. (N11, 36-vuotias nainen, toimi vapaaehtoisena vammaisjärjestössä).

Vaikka ryhmään kuuluvat olivat itseohjautuvia ja arvostivat itsenäisyyttä ja riippumatonta ajattelua, monet heistä ihailivat vanhempiaan tai isovanhempiaan ja heidän arvojaan, joiden kokivat vaikuttaneen omiin arvoihinsa. Alla haastateltava kuvaa lapsuudenkotinsa vaikutusta omaan arvomaailmaansa ja sen motivoimaan vapaaehtoistoimintaansa. "meil on puhuttu aina politiikkaa.. niinku pienest asti. --- Käytiin vappumarsseilla ja oli sellast tota.. ehkä vähän sellast niinku aatteen paloo vois sanoo. Kyl mä luulen, et se varmaan vaikuttaa jonkin verran." (N4, 26-vuotias nainen, toimi vapaaehtoisena luomuruokapiirissä ja luonnonsuojeluyhdistyksessä).

Lainaus kuvaa myös useissa haastatteluissa tyypillistä tapaa luoda jatkumoita omaan elämäntarinaan, mikä identiteettiteorioiden mukaan on koherentille identiteetille myös välttämätöntä.

Neljä haastateltavaa ryhmiteltiin auttaja-identiteettiryhmään (F2, F5, M6, M7). He konstruoivat identiteettejä, joiden keskiössä oli auttaminen. Kaikkien haastatteluissa keskeisin imago oli hahmo, jonka arvot ja elämäntyyli keskittyivät auttamiseen. Seuraava lainaus kuvaa heidän vapaaehtoistoimintaan liittyvää arvosuuntaustaan hyvin.

"vapaaehtostyös... joskus siihen menee.. ajautuu semmoset ihmiset, jotka ei oikeesti tee sitä työtä, et tekee sitä jonkun muun syyn (kuin auttamisen) takia... ne haluu jonnekki CV:seen listan siitä, et olen siinä ja tossa ja tossa... Mä en tykkää sit taas semmosest, ku se ei oo semmost... rehellistä (N2: 32-vuotias nainen, vapaaehtoisena nuorten ja vankien parissa). 
Hyväntahtoisuus oli tähän ryhmään ryhmitellyille keskeinen arvo. Muut vapaaehtoistoiminnan motiivit kuin auttamishalu saatettiin jopa nähdä epärehellisinä. Kaikki ryhmän haastateltavat toimivat vapaaehtoisena kentillä, joilla autettiin toisia ihmisiä. Heidän jotkin pohdintansa liittyivät myös universalistisiin arvoihin (joka samoin kuin hyväntahtoisuus suuntautuu itsen ylittämiseen), kuten vaikuttajaidentiteetti-ryhmään ryhmitellyillä. Auttajien arvot painottuivat kuitenkin enemmän säilyttämiseen kuin avoimuuteen muutokselle (Schwartzin 1992 teoriaa soveltaen).

Kolme auttajien ryhmään ryhmitellyistä halusi auttaa erityisesti ihmisiä, joiden tilanteet jollakin tavalla liittyivät heidän omiin kokemuksiinsa. Haastateltavat, joilla oli kokemuksia väkivallasta tai alkoholismista lapsuudessaan, halusivat auttaa lapsia ja nuoria samankaltaisissa tilanteissa. Vapaaehtoistoiminnan motivaatio nousi näiden lasten ja nuorten tilanteiden ja tarpeiden ymmärtämisestä. Sekä kokemukset autetuksi tulemisesta että ilman apua jäämisestä motivoivat näitä vapaaehtoisia auttamaan. Vapaaehtoiset myös löysivät menneisyydestään lähes poikkeuksetta ihmisen, joka oli toiminut arvojen ja auttamisidentiteetin roolimallina, kuten vapaaehtoinen, joka oli turvattomassa lapsuudessa löytänyt roolimallin muita auttavasta, vahvasta isoäidistä.

"Mä oon melkein pienest asti ollu sitä mieltä, et mä haluun olla niin kuin mamma." (N5: 24-vuotias nainen, vapaaehtoisena uskonnollisessa yhteisössä ja lasten parissa).

Osalle haastateltavista vahvuus ja toisten auttaminen olivat muodostuneet selviytymisstrategioiksi. Tämä korostaa myös auttamisen jatkuvuuden tärkeyttä identiteetissä. Vapaaehtoistoiminta mahdollisti tämän identiteetin vahvistamisen ja yläpidon heille, jotka olivat paitsi selviytyneet vaikeista kokemuksistaan myös kääntäneet omat vaikeutensa muiden hyväksi.

Uskonnollisen identiteetin ryhmään ryhmiteltiin neljä haastateltavaa (F1, M2, M3, F6), joille uskonto oli tärkein merkitysjärjestelmä. He toimivat vapaaehtoisina kristillisissä organisaatioissa tai yhteisöissä, ja usko oli heille tapa kuvata vapaaehtoistoiminnan motivaatiotaan. Kokemukset johdatuksesta, uskonnollisen yhteisön löytäminen, uskonratkaisut ja Jumalan palveleminen olivat elämänkaarien tärkeimpiä teemoja. Kaikki mainitsivat kristilliset arvot ohjaaviksi periaatteikseen, mutta kokivat arvojen sisällön keskenään osin eri tavoin. Itsekkyys tuomittiin kaikissa haastatteluissa ja hyväntahtoisuutta ja lähimmäisenrakkautta korostettiin. Niiden lisäksi eri haastatteluissa korostettiin esimerkiksi suoriutumista, työtä tai yhteisöllisyyttä.

Arvot olivat tässä ryhmässä kuitenkin vähemmän merkittäviä kuin muissa ryhmissä. Uskonto nähtiin ohjaavana periaatteena arvojen sijaan. Muissakin identiteettityyppiryhmissä oli uskonnollisia vapaaehtoisia, mutta heidän vapaaehtoistoimintaan liittämänsä identiteetit eivät rakentuneet uskonnon ympärille. Uskonto saattoi vahvistaa arvoja, kuten hyväntahtoisuutta, ja se saatettiin myös nähdä arvojen lähteenä, mutta uskonto itsessään ei ollut arvo eikä uskova ihminen yhtä keskeinen hahmo narraatioissa. Yksi uskonnollisen identiteetin ryhmään ryhmitellyistä kuvasi hyvin suoraviivaisesti, että vapaaehtoistoiminnan "motiivina on kuitenkin aika pitkälle evankeliumin eteenpäin vieminen” (M3: A 32-vuotias mies, vapaaehtoisena lasten ja nuorten parissa uskonnollisissa organisaatioissa Suomessa ja Venäjällä). Uskonto linkittyi useisiin vapaaehtoistoimintaan motivoiviin rakenteisiin. Vapaaehtoisuus oli kutsumus, tapa olla osa uskonnollista yhteisöä, ja tapa antaa takaisin yhteisölle, jolta oli saanut paljon. Seuraava lainaus kuvaa kutsumukseen liittyvän uskonnollisen motiivin voimakkuutta.

"kun on kutsu Jumalalta, niin siitä vaan ei pääse niinku eroon. Et sä et.. Et jos mä olisin tekemättä (vapaaehtoistyötä), ni mä voisin paljon huonommin, ku mitä, et mä teen. Et tietyl tavalla, vaiks se onki monesti raskast, siit joutuu maksaa sen hinnan, ja se on tietynlainen uhraus, niin tota sitä ei kuitenkaan voi olla tekemättä. (M2: 26-vuotias mies, vapaaehtoisena nuorten parissa ja kristillisessä opiskelijajärjestössä).

Vapaaehtoistoiminta näyttäytyi haastateltavalle siis jonain, jota ei voinut jättää tekemättä, koska kutsumus oli niin vastaansanomaton. Vapaaehtoistoimin- 
nalla ei ollut merkittävää arvoa itsessään vaan se esitettiin näissä haastatteluissa uskonnollisen identiteetin ilmaisemisena.

Kolme haastateltavaa ryhmiteltiin yhteisölliseen arvoidentiteettityyppiryhmään (M3, F7, M12). Heille yhteisöt, kuten perhe tai opiskelijajärjestö, ja yhteisöllisyys olivat tärkeitä asioita yleisesti ja sekä vapaaehtoistoimintaan liittyen. Yhteisöllisyyden, hyväntahtoisuuden ja perhearvojen ihanteet olivat merkittäviä myös moraalisissa kannoissa. Heidän arvonsa suuntautuivat säilyttävyyteen ja itsen ylittämiseen (Schwartzin 1992 mukaan). Universalismi ei ollut olennaista, vaan he pyrkivät auttamaan nimenomaan sisäryhmiin ja lähiyhteisöihin kuuluvia ihmisiä. Tämä erotti heidät myös auttaja-identiteettiryhmään ryhmitellyistä vapaaehtoisista. Yhteisöllisten hyväntahtoisuus suuntautui enemmän kohti lojaalisuutta. Vapaaehtoistoiminta kietoutui yhteen oman elämän yhteisöjen kanssa. Esimerkiksi lasten ja nuorten bändikerhoa vetävä haastateltava kuvasi motiiviaan seuraavasti:

"Ne (omat lapset) innostu kotona ja mä aattelin, et no mikä ettei, tätähän voi jatkaa sitten koulussakin (N5: 32-vuotias mies, vapaaehtoisena lasten ja nuorten musiikki- ja urheilutoiminnassa).

Vapaaehtoistoiminta liittyi siis omiin lapsiin, mutta myös yhteisöön, lasten kouluun. Toiselle vapaaehtoiselle vapaaehtoistoiminnan olennainen motiivi oli, että se liittyy omaan elämänpiiriin, yhteisöön, jossa häntä tarvitaan:

"aina semmonen, mikä liittyy siihen niinkun omaan elinpiiriin (motivoi) ja.. Samalla tavalla kun mä nyt oon meidän taloyhtiön hallituksessa, mikä niinkun tuli mukaan, et kävin kokouksessa, ja siellä selkeesti tarvittiin myös väkeä sinne, niin liityin mukaan." (M12, 27-vuotias mies, vapaaehtoisena opiskelijajärjestössä ja taloyhtiössä).

Vapaaehtoistoiminta oli tapa liittyä yhteisöihin ja antaa niille osaamistaan. Lasten tai puolisoiden harrastukset, työyhteisöt ja opiskelijayhteisöt olivat tyypillisiä yhteisöjä, joiden kautta ja vuoksi haastateltavat osallistuivat vapaaehtoistoimintaan. Merkittävää oli yhteisön ja sen ihmisten auttaminen tai hyödyksi ole- minen. Samalla vapaaehtoiset kokivat vahvistavansa yhteisöllisyyttä lähipiirissään ja yhteiskunnassa.

Suoriutuja-identiteettiryhmään ryhmiteltiin kaksi vapaaehtoista (M8, F12), joille olennaista oli asioiden saavuttaminen ja elämässä eteneminen. He toimivat vapaaehtoisina luottamustehtävissä poliittisessa puolueessa ja uskonnollisessa järjestössä, joiden tehtävissä ja vapaaehtoispositioissa eteneminen oli heille palkitsevaa. He arvostivat yhteiskunnallista järjestystä ja halusivat olla hyviä kansalaisia, kritisoivat tehottomuutta ja saamattomuutta. Arvot suuntautuivat säilyttävyyteen ja itsen korostamiseen. Myös hyväntahtoisuus oli mukana arvokokonaisuuksissa, muttei yhtä merkittävänä kuin suoriutuminen ja turvallisuus. Seuraava lainaus kuvaa ylpeyttä omasta onnistumisesta ja aktiivisuudesta vapaaehtoisena.

"Mä oon parempi kun moni muu siinä. Pakko sanoo (nauraa) pakko tunnustaa, et kyllä rehellisesti voi sanoo, et ei muuta kun tekemään siitä, ni katotaan mikä on lopputulos, että. Lähtökohta on silleen, et mul on vähemmän sanoja kun tekoja. Siis mä niinku toimin. --- Mä oon suora ja avoin ja rohkee, ja uskallan kyllä esittää mielipiteeni, mut ennemmin mä toimin, ku jauhan." (M8: 36-vuotias mies, vapaaehtoisena uskonnollisen organisaation lapsi- ja nuorisotyössä ja urheilun parissa).

Vapaaehtoinen kuvaa, miten saa asioita aikaiseksi ja on siksi parempi kuin moni muu. Vapaaehtoistoiminta näyttäytyy kenttänä, jolla hän saa laittaa lahjansa ja energiansa käyttöön.

\section{VAPAAEHTOISTOIMINTA ON ARVOJEN VÄLITTÄMISEN JA HUOLENPIDON KEIDAS}

Vapaaehtoistoimintaan haastatteluissa liitetyt arvot vaihtelivat itsen ylittämisestä itsen korostamiseen ja säilyttävyydestä avoimuudelle muutokseen. Lähes kaikki Schwartzin (1992) perusarvot liitettiin vapaaehtoistoimintaan ainakin jossakin haastattelussa. Aiempi tutkimus on liittänyt erityisesti itsen ylittävät, muihin suuntautuvat arvot vapaaehtoistoimintaan ja auttamiseen (esim. Clary ym. 1998). Käsillä olevan tutkimuksen tulokset kuitenkin esittävät vapaaehtoistoiminnan merkityksiltään verrattain väljänä kenttänä, jolla yksilö voi toteuttaa hyvinkin erilaisia 
arvoja. Moninaisuuden mahdollisuus tekee vapaaehtoistoiminnasta jopa ihanteellisen kentän refleksiiviselle identiteettityölle. Jokainen vapaaehtoinen voi halutessaan soveltaa toimintaa omiin tarpeisiinsa.

Huolimatta eri arvoidentiteettityyppien erilaisista painotuksista vapaaehtoistoiminta liitettiin niissä laajasti auttamisen, huolenpidon ja välittämisen merkityksiin. Auttamishalu on yleisin eksplikoitu vapaaehtoistoiminnan motiivi erilaisissa vapaaehtoistoiminnan tutkimuksissa ja se näyttää korostuvan suomalaisessa kontekstissa.

13 maata käsittävän kyselytutkimuksen tuloksissa (Grönlund 2012a) suomalaiset vastaajat pitivät auttamishaluun liittyviä motiiveja itselleen tärkeämpinä kuin minkään muun tutkimukseen osallistuneen maan vastaajat. Tasa-arvoa korostavien kulttuuristen arvojen maissa, joihin Suomi Schwartzin (1999) mukaan kuuluu, opiskelijat arvioivat auttamishaluun liittyvät motiivit tilastollisesti merkitsevästi tärkeämmiksi vapaaehtoistoiminnalleen kuin muiden maiden opiskelijat. Konteksti ohjaa vapaaehtoistoiminnan saamia merkityksiä. Esimerkiksi tutkimuksen yhdysvaltalaiset opiskelijat, joiden kulttuuriset arvot ovat valta ja suoriutuminen, painottivat tutkimuksessa Suomea enemmän vapaaehtoistoimintaa hyödyllisenä omalle uralleen, CV:lle tai verkostoilleen.

Suomessa pääkaupunkiseudun nuorille aikuisille tehdyn kyselyn vastauksissa kiinnostavimpina vapaaehtoistoiminnan muotoina olivat toiminta lasten ja nuorten parissa sekä vanhusten, vammaisten ja huono-osaisten auttaminen. Nämä ihmisten suoraan auttamiseen liittyvät toimintamuodot koettiin kiinnostaviksi useammin kuin esimerkiksi vapaaehtoistoiminta urheilun tai kulttuurin parissa (Grönlund \& Pessi 2008). Suomalaiset nuoret aikuiset näyttävät siis myös määrällisten tutkimusten valossa pitävän vapaaehtoistoimintaa kiinnostavana erityisesti auttamiseen liittyvien syiden vuoksi.

Ajassamme on nähtävissä yhteiskunnallinen muutos ja murros, jossa auttamisen, huolenpidon ja välittämisen arvot ovat siirtymässä syrjään ja markkinatalouden logiikka ja sen kovat tausta-arvot saavat enemmän ohjaavaa valtaa. Esimerkiksi perinteisesti huolenpitoa edustanut julkinen sektori toimii ajassamme yhä enemmän markkinatalouden logiikalla
(Saari \& Pessi 2011). Hyvinvointipalveluiden ulkoistaminen, kilpailutus, tehokkuusajattelu ja tuottavuuden taloutta korostavat mittarit ohjaavat julkisen sektorin toimintaa. Tässä yhteydessä vapaaehtoistoiminta näyttäytyy tietynlaisena välittämisen ja auttamisen keitaana. Ajassamme korostuvat myös monet muut trendit, jotka voi nähdä vastakehityksenä ja jopa kapinana tehokkuusajattelulle ja kilpailukulttuurille, kuten down shifting, kotoilu ja lähiruoka. Erityisesti nuoret aikuiset vaikuttavat kyllästyneen suorittamisorientaatioon. Myös melko tuore nuorten arvotutkimus kertoo, että peräti kolme neljäsosaa nuorista oli huolissaan suomalaisten arvomaailman kovenemisesta (Nuorten arvot ja elämä 2009).

Nuorten aikuisten vapaaehtoistoiminta näyttäytyy siis tekona, jolla he voivat ammentaa omaan elämäänsä

Auttamishalu

ON YLEISIN

EKSPLIKOITU

VAPAAEHTOIS-

TOIMINNAN

MOTIIVI

ERILAISISSA

VAPAAEHTOIS-

TOIMINNAN

TUTKIMUKSISSA. ja identiteettiinsä tärkeinä pitämiään, yhteiskunnassa muuten paitsiossa olevia arvoja. Samalla liike on kaksisuuntainen: vapaaehtoistoiminta on monille teko, jolla pyritään vaikuttamaan yhteiskuntaan. Tutkimuksessa haastateltu nuori nainen kuvasi tätä seuraavasti:

"emmä tiedä onks se naiivia, mut mä aattelen ite niin, et nyt mä ainaki teen jotain. Saa niinku sellasen lohdutuksen tunteen siitä. kyl mä tajuun sen ihan varsin hyvin, ettei se oo mitään niinku maailmaa mullistavaa, mitä mä teen. Mut mä teen silti jotain." (N4, 26-vuotias nainen, toimi vapaaehtoisena luomuruokapiirissä ja luonnonsuojeluyhdistyksessä).

\section{POHDINTA JA JOHTOPÄÄTÖKSET}

Edellä on esitelty perusarvojen (Schwartz 1992), narratiivisen identiteetin (McAdams 2001, 2006) 
ja arvoidentiteetin (Hitlin 2007) teoreettiset näkökulmat välineinä vapaaehtoistoiminnan, arvojen ja identiteetin yhteyksien ymmärtämiseen. Näkemys identiteetistä narratiivisena prosessina sekä tälle näkemykselle perustuvat tutkimusmenetelmät tarjoavat mielenkiintoisen tavan tutkia identiteetin ja arvojen haastavia teemoja sekä sitä, miten yksilöt niitä vapaaehtoistoiminnassa ilmaisevat ja kokevat. Vapaaehtoistoiminnan - ja toki monen muunkin toiminnan kentän - tutkimus voisi saada lisäarvoa näiden näkökulmien hyödyntämisestä.

Laadullisessa tutkimuksessa tutkijan yksilölliset näkemykset ovat olennaisia. Toinen tutkija olisi voinut päätyä erilaisiin näkökulmiin ja tuloksiin. ${ }^{3}$ Tutkimuksen tulokset myös perustuvat rajalliseen määrään haastatteluja, eikä niitä voi suoraan yleistää. Vapaaehtoiset, joilla on motivaatiota ja kiinnostusta itsen reflektointiin, saattavat myös suostua helpommin tutkimushaastatteluihin kuin ne, joille se on epätyypillisempää. Vapaaehtoisen kulttuurinen konteksti ja sosiaalinen ympäristö vaikuttavat haastateltavan identiteettiin ja sen narratiiviseen konstruointiin samoin kuin arvoihin ja vapaaehtoistoiminnan mahdollisuuksiin. Tämä tutkimus perustuu haastatteluihin yhdellä alueella Suomessa.

Tutkimuksen 24 haastateltavasta 17 yhdisti vapaaehtoistoiminnan arvoidentiteettiin haastatteluissa. Vaikka laadullisen tutkimuksen tavoite ei ole yleistää, voidaan tuloksen perusteella olettaa, että vapaaehtoistoiminta kytkeytyy arvoidentiteetteihin myös monilla muilla vapaaehtoisilla. Toisaalta on huomionarvoista, että seitsemän haastateltavaa ei liittänyt vapaaehtoistoimintaa ydinarvoihinsa tai identiteettiinsä haastatteluissa. Tämä joukko muodostaa yli neljäsosan haastatelluista. Myös tätä voidaan pitää tutkimuksen yhtenä tuloksena. Väljyydessään vapaaehtoistoiminta tarjoaa areenan paitsi syvälliseen identiteettityöhön ja arvopohdintaan, myös toimintaan, joka ei liity näihin ulottuvuuksiin. Vapaaehtoistoiminta voi tarjota osallistumismahdollisuuden niille, joille toiminnallisuus on luontevampaa kuin refleksiivisyys.

Nuoret ikäryhmät näyttävät tarjoavan erityisen moniulotteisen ja kiehtovan arvotutkimuskentän. Monet arvotutkimukset osoittavat, että nuoret ikäryhmät pitävät hedonististisia arvoja verrattain tärkeinä itselleen (esim. Puohiniemi 2006). Siitä huolimatta he ovat erittäin kiinnostuneita vapaaehtoistoiminnasta ja auttamisesta (esim. Grönlund \& Pessi 2008; Pessi 2008). Fragmentoitunut sosiaalinen konteksti saattaa näkyä nuorten ikäryhmien tavoissa käyttää ja toteuttaa arvoja (esim. Helve 1999). Hedonismiin suuntautunut yksilö voi toimia vapaaehtoistoiminnan kentällä muilla arvoulottuvuuksilla vallitsevan arvoulottuvuutensa rinnalla. Yksilön arvot eivät koskaan ole yksiulotteiset, ja arvoulottuvuuksien dynaaminen käyttö eri tilanteissa tulisi ottaa huomioon erityisesti nuoria ikäryhmiä tutkittaessa. Perinteinen arvotutkimus on mahdollisesti jossain määrin epäonnistunut ymmärtämään nyanssista yhteyttä, joka nuorten aikuisten arvojen ja auttamisen välillä jälkitraditionaalisissa länsimaisissa yhteiskunnissa on. Lisää syväluotaavia tutkimuksia holistisin laadullisin menetelmin tarvitaan, jotta arvojen ja (vapaaehtois)toiminnan yhteyksiä toisiinsa ja identiteettiin voidaan ymmärtää paremmin. Tutkimuksia tarvitaan myös muiden ikäryhmien tavoista liittää vapaaehtoistoiminta arvoihinsa ja identiteettiinsä esimerkiksi erilaisissa elämänkriiseissä tai vaikkapa eläkkeelle jäämisen yhteydessä.

Tutkimuksen tuloksia on hyödyllistä myös soveltaa käytäntöön. Vapaaehtoisten yksilöllisiä tarpeita ja näkökulmia ymmärtämällä toiminnan organisoijat voivat tarjota heille sopivia toimintamuotoja, ja vapaaehtoistoiminta voi aiempaakin paremmin toimia identiteettityön ja arvopohdintojen kenttänä. Tulokset korostavat myös vapaaehtoistoiminnan mahdollisuuksia kasvatuksellisena kenttänä, koska se kietoutuu arvoihin ja moraalisiin kysymyksiin. Koululaisten ja opiskelijoiden osallistuminen vapaaehtoistehtäviin osana opetusta herättää kiinnostusta myös suomalaisessa yhteiskunnassa ja oppilaissa (esim. Grönlund 2012; Vetoomus opetusministeri Henna Virkkuselle ja opetushallitukselle, 2010). Kypsän moraalisen ja yhteiskunnallisen toiminnan elementit voidaan jakaa kolmeen ulottuvuuteen. Ensimmäinen, tiedollinen aspekti tarkoittaa tietoa ja ymmärrystä instituutioista sekä eettisistä ja demokraattisista periaatteista. Toinen, motivaatio tarkoittaa halua toimia oikein, tavoitteita ja arvoja. Kolmas, käytännön 
toiminta tarkoittaa sitä, että tietoa ja motivaatiota sovelletaan käytäntöön ja opitaan toiminnan kautta. Nämä kolme aluetta ovat keskenään vuorovaikutuksessa ja moraali- ja kansalaiskasvatuksen on ajateltu olevan tehokkainta, kun se kohdistuu niihin kaikkiin (Colby 2005; ks. myös Grönlund \& Pessi 2008). Aiempi tutkimus on myös löytänyt positiivisia yhteyksiä muun muassa oppilaitosten vapaaehtoistoimintaohjelmien ja tulevan vapaaehtoistoiminnan välillä (Haski-Leventhal ym. 2010. Nuorten aikuisten vapaaehtoistoimintaan liittämien yksilöllisten proses- sien ymmärtämisestä voi olla hyötyä, mikäli vapaaehtoistoimintaa halutaan Suomessa jatkossa hyödyntää aiempaa enemmän kasvatuksessa.

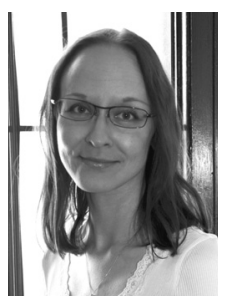

Henrietta Grönlund

Tutkijatohtori

Käytännöllisen teologian osasto

Teologinen tiedekunta

Helsingin yliopisto

\section{KIRJALLISUUS}

Blasi, A. (1993). The development of identity: Some implications for moral functioning. In Noam, G. G. \& Wren, T. E. (Eds.) The moral self. Cambridge, MA: MIT Press. 99-122.

Clary, E. G., Snyder, M., Ridge, R. D., Copeland, J., Stukas, A. A. , Haugen, J. \& Miene, P. (1998). Understanding and assessing the motivations of volunteers: a functional approach. Journal of Personality and Social Psychology, 74, 1516-1530.

Colby, A. (2005). Moraali- ja kansalaiskehityksen ulottuvuudet. Teoksessa Pirttilä-Backman, A-M., Ahokas, M., Myyry, L., \& Lähteenoja, S. (toim.) Arvot, moraali ja yhteiskunta. Sosiaalipsykologisian näkökulmia yhteiskunnan muutokseen. Helsinki: Gaudeamus. 37-65.

Erikson, E. H. (1968). Identity: Youth and crisis. New York: Norton.

Grönlund, H. (2011) Identity and volunteering intertwined: Reflections from the values of young adults. Voluntas, International Journal of Voluntary \& Nonprofit Organizations 22(3), 852-874.

Grönlund, H. (2012a) Volunteerism as a mirror of individuals and society: reflections from young adults in Finland. Helsinki: University of Helsinki. (Diss.).

Grönlund, H (2012b). Raportti kyselystä vapaaehtoistoiminnasta koulussa 2012. Julkaisematon raportti, tekijän hallussa.

Grönlund H. \& Pessi, A. B. (2008). Osallisuuden asenteet ja teot. Nuoret ikäryhmät vapaaehtoistoiminnassa. In Polarisoituva nuoruus? Nuorten elinolot -vuosikirja. Autio, M., Eräranta, K. \& Myllyniemi, S. (toim.) Helsinki: Nuorisotutkimusseura / Nuorisotutkimusverkosto, julkaisuja 84 \& Nuorisoasiain neuvottelukunta \& Stakes. 127-137.
Haski-Leventhal, D., Grönlund, H., Holmes, K., Meijs, L. C. P. M., Cnaan, R. A., Handy, F., Brudney, J., Hustinx, L., Kang, C., Kassam, M., Pessi, A. B., Ranade, B., Smith, K. A., Yamauchi, N., \& Zrinscak, S. (2010). Service-Learning: Findings From a 14-Nation Study. Journal of Nonprofit \& Public Sector Marketing, 22(3), 161-179.

Helve, H. (1999). Multiculturalism and values of young people. Diskus 5. http://www.uni-marburg.de/ religionswissenschaft/journal/diskus (ladattu 23.7.2010).

Hitlin, S. (2007). Doing good, feeling good: Values and the self's moral center. The Journal of Positive Psychology 2(4), 249-259.

Kohlberg, L. (1975). Collected papers on moral development and moral education. Harvard Graduate School of Education, Cambridge.

Marta, E. \& Pozzi, M. (2008). Young People and Volunteerism: A Model of Sustained Volunteerism During the Transition to Adulthood. Journal of Adult Development 15, 35-46.

McAdams, D. P. (2001). The psychology of life stories. Review of General Psychology 5, 100-122.

McAdams, D. P. (2006). The role of narrative in personality psychology today. Narrative Inquiry 16(1), 11-18.

Musick, M.A. \& Wilson, J. (2008). Volunteers: a social profile. Bloomington \& Indianopolis: Indiana University Press.

Nylund, M. \& Yeung, A. B. (toim.) (2005). Vapaaehtoistoiminta. Anti, arvot ja osallisuus. Tampere: Vastapaino.

Pessi, A. B. (2008). Suomalaiset auttajina ja luottamus avun lähteisiin. RAY:n juhlavuoden kansalaiskyselyn tulokset. Avustustoiminnan raportteja 19. Helsinki: RAY. 
Puohiniemi, M. (2006). Täsmäelämän ja uusyhteisöllisyyden aika. Vantaa: Limor kustannus.

Rehberg, W. (2005). Altruistic Individuals: Motivations for International Volunteering Among Young Adults in Switzerland. Voluntas: International Journal of Vheoluntary and Nonprofit Organizations, 16(2), 109-122.

Roberts, B. (2002) Biographical Research. Understanding Social Research. Series editor Alan Bryman. Buckingham, Philadelphia: Open University Press.

Rochester, C., Paine, A. E., Howlett, S. \& Zimmeck, M. (2010). Volunteering and Society in the 21st Century. Hampshire: Palgrave Macmillan.

Rokeach, M. (1973). The nature of human values. New York: Free Press.

Saari, J. \& Pessi, A. B. (2011). Auttaminen kilpailukykyyhteiskunnassa. Teoksessa Hyvien ihmisten maa. Auttaminen kilpailukyky-yhteiskunnassa. Pessi, A. B. \& Saari, J. (toim.) Helsinki: Diakoniaammattikorkeakoulu. 15-41.

Schwartz, S. H. (1992). Universals in the content and structure of values: Theoretical advances and empirical tests in 20 countries. Teoksessa M. P. Zanna (toim.). Advances in experimental social psychology 25. 1-65.

Schwartz, S. H. (1999). A Theory of Cultural Values and Some Implications for Work. Applied Psychology: An International Review 48(1), 23-47.

2011 State of the World's Volunteerism Report. Universal Values for Global Well-being (2011). United Nations Volunteers. http://www.unric.org/en/images/ stories/2011/PDF/SWVR\%20Report\%20[Eng].pdf (ladattu 12.7.2012.)

Study on Volunteering in the European Union. Country Report Finland (2011). http://europa.eu/volunteering/ en/content/study-volunteering-european-unioncountry-report-finland (ladattu 24.7.2012.)

Taylor, C. (1989). Sources of the Self: The Making of Modern Identity. Harvard, Cambridge, MA.

Vetoomus opetusministeri Henna Virkkuselle ja opetushallitukselle (2010). http://www. kansalaisareena.fi/vapaaehtoistoiminta_osaksi_ opetussuunnitelmaa_2010.pdf (ladattu 1.12.2012.)

Yeung, A. B. (2001). Vapaaehtoistoiminta osana kansalaisyhteiskuntaa - ihanteita vai todellisuutta? Helsinki: Sosiaali- ja terveysjärjestöjen yhteistyöyhdistys YTY ry.

\section{VIITTEET}

1 Aineistot on analysoitu ja tulokset raportoitu primaaristi väitöskirjassani ja sen neljässä osajulkaisussa, jotka on julkaistu itsenäisinä artikkeleina kansainvälisissä tieteellisissä aikakauskirjoissa (Grönlund 2012a).

2 Haastateltavat rekrytoitiin kyselytutkimuksen kautta. Urbaani usko -tutkimushankkeessa (ks. tarkemmin Grönlund 2012a) haastateltiin vuonna 2004 puhelimitse 1000 20-39-vuotiasta nuorta aikuista, joilta tiedusteltiin muun muassa vapaaehtoistoimintaan ja uskonnollisuuteen liittyviä asioita. Vapaaehtoisena toimineilta tiedusteltiin, haluaisivatko he osallistua myöhemmin tutkimushaastatteluun. Halukkaista valittiin tämän artikkelin aineiston haastateltavat. Koska samojen haastattelujen avulla haluttiin tutkia uskonnollisuuden ja vapaaehtoistoiminnan yhteyksiä, haastateltaviksi valittiin vapaaehtoisia, jotka edustivat keskenään erilaista uskonnollisuutta. Kyselyaineiston vastaajat ryhmiteltiin ryhmittelyanalyysillä neljään ryhmään erilaisiin uskonnollisiin väittämiin asennoitumisen mukaan. Ryhmistä ensimmäinen edusti perinteistä, kristillistä uskoa, toinen väljempää spirituaalisuutta, kolmas epävarmaa uskonnollisuutta, neljäs uskonnottomuutta (ks. tarkemmin Grönlund 2012a). Jokaisesta ryhmästä haastateltiin kolme naista ja kolme miestä. Ryhmittelyanalyysillä muodostetut ryhmät olivat erikokoisia eikä haastateltavien valintaa suhteutettu niiden kokoihin. Näin ollen esimerkiksi perinteistä, kristillistä uskoa edustavien haastateltavien joukko on suhteessa suurempi kuin kyselyaineistossa. Laadullinen tutkimus ei pyri yleistettävyyteen, ja haastatteluaineiston monipuolisuutta pidettiin tärkeämpänä kuin sen edustavuutta. Haastateltavien valintatapa on kuitenkin syytä huomioida, sillä se vaikuttaa tutkimustuloksiin, erityisesti uskonnollisuuden verrattain keskeiseen rooliin. Haastatelluista osa oli työssäkäyviä, osa opiskelijoita, osa äitiyslomalla. Osalla oli lapsia, osalla ei, osa oli naimisissa, osa eli yksin. Elämäntilannetta ei huomioitu haastateltavia valittaessa vaan valintaa ohjasivat vapaaehtoistoiminta ja uskonnollisuustyyppi (mukaan lukien uskonnottomuus).

3 Tutkijan asemasta ja suhteesta tutkittavaan ilmiöön ks. tarkemmin Grönlund 2012a. 